\title{
Media Literacy in Extracurricular Activities of Journalism to Strengthen Civic Education
}

\author{
Yenik Wahyuningsih, Erny Roesminingsih, Sri Setyowati \\ Universitas Negeri Surabaya \\ Surabaya, Indonesia \\ yenikwahyuningsih16070845023@mhs.unesa.ac.id
}

\begin{abstract}
In the 21st century, the millennial generation is the multicultural society. They need space to actualize the value of nation's character in implementing civic education. Extracurricular activities of journalism can help them develop balanced interest and talent with media literacy program. This research study used a combination of research methods with concurrent embedded strategy model, with a total sample of 27 students who participated in extracurricular activities of journalism at different grade levels in an integrated Islamic elementary school in Surabaya. This media literacy activity has a positive impact on them. The results of the research show the work of media literacy results in the anthology of poetry, comics, short stories and photography which contain portraits of the life of the people they meet and adjusted to their point of view, as many as 21 of 27 children have adaptive behaviors such as respecting their non-Muslim friends and not bullying.
\end{abstract}

Keywords-Civic education; Media Literacy; Elementary School; Multicultural

\section{INTRODUCTION}

Media literacy also involves multimedia production as students learn to create messages with different media and technology. In composing with image, language and sound, students must consider audience, purpose, genre, form, and context. By creating presentations, Internet blogs, videos, podcasts and other forms of expression and communication, students gain confidence in using their voices to explore the relationship between information, knowledge, and power. [1]

Simplistic rhetoric of media literacy, which seems to be designed to have something-for-everyone, with no apparent ideological agenda concerning education reform, broadcast regulation, commercialism in the classroom, media ownership and centralization, racism, sexism, and other social injustices. That media literacy must be seen as a tool for educational, social or political change.[2]

A variety of English education organizations, including the National Council of

Teachers of English (NCTE) and the Conference on English Education (CEE) have also recognized the need to include both the critical analysis of nonprint texts and multimodal creative production projects into the secondary English curriculum, and the Common Core standards seems to support media literacy when it states, "To be ready for college, workforce training, and life in a technological society, students need the ability to gather, comprehend, evaluate, synthesize, and report on information and ideas, to conduct original research in order to answer questions or solve problems, and to analyze and create a high volume and extensive range of print and nonprint texts in media forms old and new"[3]

Integrated Islamic Primary School Ghilmani (SDIT Ghilmani) is an Islamic Elementary School which has the mission of "Robbani Generation Outstanding Achievement and Mandiri" and its mission are: (1) making a superior generation based on Al Qur'an and Hadith, (2) developing interests and talents of students to achieve academic and non-academic achievement optimally, (3) improve the quality of human resources, (4) make students who have life skills, (5) make students who have high awareness in worship day -day.

SDIT Ghimani has the following objectives: (1) improvement of students' ability in the field of tahfidz al Qur'an in every grade level, (2) improvement of achievement through competition and academic development in the form of student product, (3) (4) the implementation of activities that support the activity, the independence of students for future provision in the form of extracurricular activities (5) the obligatory prayer, dhuha praying in congregation and murojaah after the dhuha prayer is done.

With the foundation of the vision, mission and objectives on points two and four listed in the mission, the authors will develop a media literacy program in extracurricular journalistic activities in SDIT Ghilmani.

Extracurricular activities of journalism is an optional extracurricular activity in SDIT Ghimani as a vehicle to build journalistic groups at the student level. This is an attempt to fill his spare time after compulsory education activities in schools that also coincide with national education programs and the national curriculum, the Minister of Education and Culture of the Republic of Indonesia No. 62 of 2014 and in line with the mission vision of SDIT Ghilmani. In the extracurricular activities of journalism, there are several competencies offered, namely the variety of writing, making wall magazines or school magazines, bulletins that are managed by teachers of extracurricular journalism and students who follow this extracurricular activity. 
Students who follow this extracurricular activity almost every year increase. The beginning of 7 students, in this academic year 2017/2018 as many as 27 students from various levels. Students who follow this extracurricular activity starts in grade 3, grade 4 and grade 5 . And there are several levels, namely the basic level, middle and advanced levels.

Today, in the 21 st-century demands for the millennial generation's readiness as a generation to be the future successor becomes a challenge for the school. Especially in this era of globalization children should be introduced to the issue of pluralism.

\section{MethoD}

The research design conducted by researchers included in the study concurrent embedded concurrent research method, with 27 research subjects, ranging from third, fourth and fifthgrade students who took journalistic extracurricular activities in Islamic elementary schools in Surabaya. In this study, researchers used questionnaires, interviews, documentation, and observation as research instruments. In data analysis, researchers collected the results of interviews, observations, questionnaires, and documentation to be sorted out. Next, the researcher used method triangulation and data source triangulation.

\section{RESULTS AND DisCUSSION}

Today, in the $21^{\text {st }}$-century demands for the millennial generation's readiness as a generation to be the future successor becomes a challenge for the school. Child's success is not only determined by academic achievement but how he can also communicate and socialize with the surrounding environment. In this study, the results of interviews with researchers with 27 children who took part in journalistic extracurricular activities and the results of their work. The results show that these children have adaptive behavior, they want to accept differences of opinion between their friends. It is also shown through their poetry that illustrates the diversity of ethnicity, culture, and religion in Indonesia, they assume that one another must respect, respect and help based on humanity and not bullying each other

As stated in the chart of the book driving skills agenda as follows:

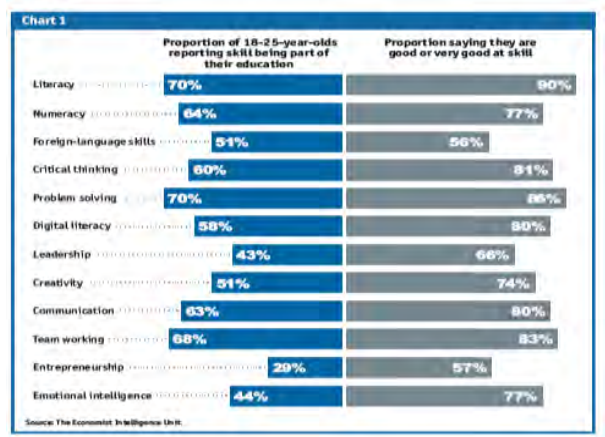

Table 1.1. Graph 1 about the capabilities needed for future generations
In the graph above proportion for the age of 18-25 years the required capability is literacy and problem solving ability $(70 \%)$, teamwork $(68 \%)$, numeracy $(64 \%)$, communication $(63 \%)$, critical thinking $(60 \%)$, digital literacy $(58 \%)$, foreign language proficiency and creativity $(51 \%)$, emotional intelligence (44\%), leadership (43\%), and entrepreneurship $(29 \%)$. In addition, in the $21^{\text {st }}$ century everyone is expected to be informed and knowledgeable people will access information efficiently and effectively, evaluate information critically and competently, and use information accurately and creatively [5]

Thus, the authors hope in extracurricular activities journalism through literacy activities as mentioned in KBBI edition V, which means: (1) Ability to write and read, (2) Knowledge of skills in a particular field or activity. Literacy, in this case, is not limited to the ability to read and write only, but also about knowledge and skills in various other fields such as digital literacy, science literacy, technological literacy and so on. Can answer the challenges of the 21 st century and can encourage the realization of school vision, mission, and goals. Given the current millennial generation, its needs are already different from baby boomers and generation $\mathrm{X}$ generation.

Besides quoting from Hendry Giroux (in Freire and Macedo: 1987) with reference to Gramsci states that:

[...] became booth a referent and mode of critique for developing form of counterhegemonic education around political project of creating a society of intellectuals (in the widest sense of term) who could grasp the importance of developing democratic public spheres as part of the struggle of modern life to fight against domination as well as take an active part in the struggle for creating the conditions necessary to make people literate, to give them a voice in both shaping and governing their society.

In the above quote, Giroux constructs a paradigmatic perspective on literacy from a critical perspective whose direction of social change is toward critical awareness. And thus, it is expected that this program can support the students of SDIT Ghilmani to be actively literate through the media in accordance with the needs and the time to achieve their achievement and independence in accordance with the vision, mission, and objectives of the school.

Every child has the opportunity to develop and grow in a society. In learning about literacy, children are indirectly taught how they must be open-minded, building the concept of diversity that they are social human beings. They also need to be invited to feel what if they are in the same position, where they experience unpleasant actions. This certainly can be expressed through the literacy activities they have carried out to produce a work.

\section{CONCLUSION AND SUGGESTION}

The results of the study show that media literacy works made by third, fourth and fifth-grade students who take journalistic extracurricular activities have a positive impact. This was manifested in several works, including the anthology of poetry, comics, short stories and photography which contained portraits of the lives of people they met and adapted 
to their point of view. A total of 21 of the 27 children have adaptive behaviors such as respecting their non-Muslim friends and not bullying.

Strengthening citizenship education through journalistic extracurricular activities helps students to be literate according to their abilities, interests, and the world. Citizenship education is important, in the era of globalization in the 21 st century, given the rapid flow of information and the influence of the issue of tolerance to be trending and it is hoped that Indonesian people will become the civil society. So from an early age, children must be introduced to civic education.

Social studies educators recognize the value of digital media literacy as an essential life skill of the 21 st century world "where the majority of information people receive comes less often from print sources and more typically from highly constructed visual images, complex sound arrangements, and multiple media formats". New skills are needed for accessing, analyzing, evaluating, creating, and distributing messages within a digital, global, and democratic society.[6]

A number of scholars have examined the relationship between digital media literacy education and civic engagement among young people. Martens and Hobbs (in press) surveyed 400 high school students in Maryland in order to assess the relationships among media literacy education, frequency of Internet use, information-gathering motivations, media literacy competencies, and civic engagement. Their results showed that participation in a media literacy program was positively related to information- seeking motives, media knowledge, and news analysis skills, which independently contributed to students' intent to engage in forms of civic engagement such as volunteering, voting and expressing political opinions in a public forum. [7]

\section{REFERENCES}

[1] R. Hobbs, K. Donnelly, J. Friesem, and M. Moen, "Learning to engage: how positive attitudes about the news, media literacy, and video production contribute to adolescent civic engagement," EMI. Educ. Media Int., vol. 50, no. 4, pp. 231-246, 2013.

[2] D. Resume, P. U. B. Date, P. U. B. Type, and E. Price, "The Seven Great Debates In the Media Literacy Movement," no. 4, 1999.

[3] R. Hobbs, Digital and Media Literacy: A Plan of Action. A White Paper on the Digital and Media Literacy. 2010.

[4] S. Jonathan, "Metode penelitian kuantitatif dan kualitatif." Graha Ilmu, 2006.

[5] B. Trilling and C. Fadel, 21st century skills: Learning for life in our times. John Wiley \& Sons, 2009.

[6] R. Hobbs, "A review of school-based initiatives in media literacy education,” Am. Behav. Sci., vol. 48, no. 1, pp. 42-59, 2004.

[7] P. Levine, "A public voice for youth: The audience problem in digital media and civic education," Civ. life online Learn. how Digit. media can Engag. youth, no. February 14, 2010, pp. 119-138, 2008. 